The Women's Health Council

Combairle Shláinte na mBan

\title{
Female Genital Mutilation/Cutting
}

A Literature Review 


\section{The Women's Heaith Council}

The Women's Health Council is a statutory body established in 1997 to advise the Minister for Health and Children on all aspects of women's health. Following a recommendation in the Report of the Second Commission on the Status of Women (1993), the national Plan for Women's Health 1997-1999 was published in 1997. One of the recommendations in the Plan was that a Women's Health Council be set up as 'a centre of expertise on women's health issues, to foster research into women's health, evaluate the success of this Plan in improving women's health and advise the Minister for Health on women's issues generally.' The mission of the Women's Health Council is to inform and influence the development of health policy to ensure the maximum health and social gain for women in Ireland. Its membership is representative of a wide range of expertise and interest in women's health.

The Women's Health Council has five functions detailed in its Statutory Instruments:

1. Advising the Minister for Health and Children on all aspects of women's health.

2. Assisting the development of national and regional policies and strategies designed to increase health gain and social gain for women.

3. Developing expertise on women's health within the health services.

4. Liaising with other relevant international bodies which have similar functions as the Council.

5. Advising other Government Ministers at their request.

The work of the Women's Health Council is guided by three principles:

Equity based on diversity - the need to develop flexible and accessible services which respond equitably to the diverse needs and situations of women

Quality in the provision and delivery of health services to all women throughout their lives

Relevance to women's health needs

In carrying out its statutory functions, the Women's Health Council has adopted the WHO definition of health, a measure reiterated in the Department of Health's 'Quality and Fairness' document (2001). This definition states that

'Health is a state of complete physical, mental and social well being'. 


\section{Contents}

Summary 2

1. Introduction 3

2. Female Genital Mutilation/Cutting 5

3. Health and Social Repercussions 8

4. The Health Sector Response 11

5. Strategies for Change: Prevention and Eradication 15

6. FGM/C: Legislative Policies 18

7. $\mathrm{FGM} / \mathrm{C}$ in Ireland 22

8. Conclusions and Recommendations 24

Appendix I: Women's Empowerment Community Consensus 27

Appendix II: African Countries Legislative Approaches 29

$\begin{array}{ll}\text { References } & 31\end{array}$ 


\section{Summary}

This report represents the result of two different strands of work by the Women's Health Council. At the beginning of 2006, due to the recent significant inward migration experienced in Ireland, the Council's board identified the promotion of the health of ethnic minority women as a key area of work in its strategic plan for the period 2007-2009. At the same time, it was also decided that the problem of gender-based violence would also be addressed through a number of research and policy initiatives. This report focuses on a health issue that marries these two concerns, Female Genital Mutilation/Cutting (FGM/C - see below for definition) and serves as an accompanying document to the recently published Violence Against Women and Health (2007) and the forthcoming study on Ethnic Minority Women and Gender-Based Violence.

Anecdotal evidence from health service providers, especially those working in reproductive health, highlighted the needs of women presenting at services who have undergone FGM/C. There was also a concern that in order to maintain cultural traditions, the practice might take root in Ireland clandestinely. From discussions with the Master of a Dublin maternity hospital the Council understands that the staff in the hospital see the effect of FGM/C on women on a regular basis presenting either as outpatients or to give birth. The Council also examined HIPE data for 2005 (ICD 10 AM) and identified a code for FGM/C treatment, repair and pregnancy. However, it is not possible to interpret the data due to a lack of systematic application.

In relation to new cases, inquiries through the Director of Public Prosecution as well as An Garda Sióchána showed that very little is known about this practice and no cases have been brought to their attention. However, the law enforcement agencies are aware that this practice might be taking place within ethnic communities and are engaging in prevention work through the Racial and Intercultural Office of An Garda Sióchána.

While FGM/C affects only a small portion of the overall number of ethnic minority women living in Ireland, it has a huge negative health impact on those women. The report provides a detailed account of the various negative health repercussions of this practice and advocates for greater awareness and training for all health professionals but especially for those working in the areas of reproductive and maternity care. It is hoped that this document will provide information to these service providers and be supported by the implementation of the Health Service Executive's Intercultural Strategy.

Finally, it is crucial that this practice does not become established in Ireland and appropriate legislative and child protection measure are put in place to prevent FGM/C. For this purpose a concert awareness raising effort is required as well as the provision of amended legislation to safeguard the health and wellbeing of the girl child and women at risk. Again, this document makes clear and simple recommendations on how legislation can be amended for this purpose and as well as advocating the engagement of the relevant ethnic communities to ensure that any new measure is implemented in a cultural sensitive way.

\footnotetext{
${ }^{1}$ Hospital In-Patient Enquiry Scheme
} 


\section{Introduction}

Violence against women remains a significant problem in all societies and Female Genital Mutilation (FGM) is one of the most severe manifestations. FGM is a harmful traditional practice and a form of violence that directly infringes upon women's (and children's) rights to physical, psychological and social health. In a joint statement, the World Health Organisation (WHO), United Nations Children's Fund (UNICEF) and United Nations Population Fund (UNFPA) collectively defined Female Genital Mutilation/Cutting as an act, which "comprises all procedures involving partial or total removal of the external female genitalia or other injury to the female genital organs whether for culture or other non-therapeutic reasons" (WHO, UNICEF, UNFPA, 1997: 3).

The issue of Female Genital Mutilation (FGM) has attracted considerable attention in recent times and debates have taken place as to the best way to refer to this practice. The phrase Female Genital Mutilation could be interpreted by some as a value loaded term that labels women as mutilated, when they may not in fact see themselves as having undergone a process of 'mutilation' per se. The use of the term mutilation is "thought to imply excessive judgement by outsiders and insensitivity toward individuals who have undergone the procedure" (Eliah, 1996:13). Women may be more accepting of the term 'cutting' as a less stigmatising way of describing the practice. Taking these issues into account, throughout this report, this procedure will be referred to as 'Female Genital Mutilation/Cutting' (FGM/C).

UNICEF estimates that approximately 135 million women and girls have undergone FGM/C, with 3 million girls and women remaining at risk of the procedure each year (Murphy, 2006). It is also calculated that 100,000 women and teenagers die from complications related to FGM/C in childbirth per annum (Abbas, 2006). Female Genital Mutilation/Cutting is known to be performed in at least 28 African, Middle Eastern and Asian countries (Jabre et al., 1997). The prevalence of FGM/C varies widely from country to country. For example, it ranges from "nearly 90 per cent or higher in Egypt, Eritrea, Mali and Sudan, to less than 50 per cent in the Central African Republic and Cote d'Ivoire, to 5 per cent in the Democratic Republic of Congo and Uganda" (Rahman and Toubia, 2000: 6) ${ }^{2}$. Increased immigration to Europe has meant that a cultural practice previously associated with the developing world has become an issue, indeed a problem that needs to be overcome in a culturally sensitive manner in European societies, including Ireland (Leye and Deblonde, 2004; Momoh, 2005).

The social, cultural and religious reasons for the continued practice of FGM/C will be outlined in this report. However, the continuance of FGM/C out of respect for culture and tradition has been rejected at international level as an unacceptable motivation (UNHCHR, 1993). It is now internationally accepted that FGM/C is a harmful cultural practice and an act of violence against the physical and emotional integrity of women and children ${ }^{3}$, wherever and however it occurs (UNIFEM, 2003; African Union, 2003). The Declaration on the Elimination of Violence

\footnotetext{
${ }^{2}$ No current prevalence rates for Asia and the Middle East were found.

${ }^{3}$ A UN report on Violence against Children (VAC) identified FGM/C as a form of VAC (Pinheiro, 2006).
} 
against Women in 1993 specifically mentions the practice of Female Genital Mutilation/ Cutting as a cultural practice that represents a form of violence and a cause of harm to women:

"The term "violence against women" means any act of gender-based violence that results in, or is likely to result in, physical, sexual or psychological harm or suffering to women, including threats of such acts, coercion or arbitrary deprivation of liberty, whether occurring in public or in private life... [including] physical, sexual and psychological violence occurring in the family, including battering, sexual abuse of female children in the household, dowry-related violence, marital rape, female genital mutilation and other traditional practices harmful to women..."

(UNHCHR, 1993)

The Women's Health Council has adopted the internationally agreed position and defines FGM/C as a form of violence against women and a human rights abuse. Inward migration to Ireland necessitates that Irish society take a proactive part in the prevention of FGM/C. Ireland should do so in a manner that is both sensitive to cultural diversity yet in an approach that gives priority to the women affected on social, physical, and emotional levels by the continued practice of FGM/C. FGM/C is not a widespread cultural practice in Ireland, but its existence does remain a characteristic within ethnic minority groups. Furthermore, because FGM/C is not medically available in Ireland, the potential for it to be practiced within ethnic minority communities could therefore occur in private and remain hidden from both authorities and the health system (Gill et al., 2006; Powell, 2004).

The aim of this literature review is to provide on overview of the reasons for the occurrence and persistence of $\mathrm{FGM} / \mathrm{C}$, and its health and social repercussions. It is intended to provide useful information for policy makers, legislators, health service providers and people working with and for women affected by FGM/C. The Council hopes that this document will inform future policy and legislative reform in this area as well as promote a coherent and coordinated response to FGM/C in health settings in Ireland.

This report will therefore outline:

1. The different forms of FGM/C;

2. The motivations for the continued practice of the FGM/C;

3. The health and social implications of FGM/C;

4. Challenges to and responses by the health sector in dealing with this practice;

5. Approaches taken to the prevention and eradication of FGM/C;

6. International and selected national legislative frameworks governing FGM/C;

7. The situation in Ireland in relation to FGM/C; and

8. Recommendations for dealing with the practice in terms of prevention and treatment in Ireland. 


\section{Female Genital Mutilation/Cutting (FGM/C)}

\subsection{Forms of FGM/C}

No one society, culture or ethnic group practices the same type or level of FGM/C at all times (UNICEF, 1998; McCloud et al., 2003; Habtemarian et al., 2003). The meaning of FGM/C is embedded in localised historical, social and cultural practices. Because of the multitude of culturally specific meanings attached to its continuance, its eradication often poses complex challenges and requires a prolonged multifaceted effort (Greunbaum, 2005).

The World Health Organisation has outlined four broad types of FGM/C depending on the severity and extent of mutilation that has occurred (2000).

Type I

Excision of the prepuce, with or without excision of part or all of the clitoris.

Type II

Excision of the clitoris with partial or total excision of the labia minora.

Types III

Excision of part or all of the external genitalia and stitching / narrowing of the vaginal opening [known as 'infibulation' or'Pharoanic circumcision'].

Type IV Pricking, piercing or incising of the clitoris and/or labia; stretching of the clitoris and/or labia; cauterization by burning of the clitoris and surrounding tissue.

Scraping Scraping of the tissue surrounding the vaginal orifice (angurya cuts) or cutting of the vagina (gishiri cuts).

Additional substance Introduction of corrosive substances or herbs into the vagina to cause bleeding or for the purpose of tightening or narrowing it; and any other procedure that falls under the definition given above.

Table 1 - Types of FGM/C 


\subsection{Prevalence and Severity}

The WHO estimates that excision of the clitoris and labia minora (Type II) is the most prevalent form of FGM/C as it accounts for $80 \%$ of all cases. However infibulation (Type III) is understood to be the most severe and most harmful to women's bodily and psychological integrity; recent estimates stand at $15 \%$ of all cases (WHO, 2000). Infibulation occurs when the entire clitoris, labia minora and most of the labia majora are cut from the body; the remaining edges are then stitched together, covering the vaginal opening, in most instances leaving a tiny hole to allow urine and menstrual blood to pass through.

FGM/C can be performed on girl children and women at any time in their lives from birth onwards. It is, however, generally performed around the ages of 5-7 or before the woman marries (McCulloch, 2004). The procedure is carried out by the girl child's or woman's female relatives or by a Traditional Birth Attendant member of the community. The practice is normally performed without the use of anaesthetic or hygienic surgical tools. This is frequently due to the level of poverty in communities, and therefore the lack of affordability of sterile equipment. Where families can afford to, the procedure is sometimes carried out in a hygienic, medicalised setting; this is, however, the exception rather than the rule ${ }^{4}$. Instruments known to be used in performing the mutilation/cutting vary from the use of sharp rocks, razor blades, kitchen knives, broken glass, or even [the use of the circumcisers'] teeth (Barstow, 1998).

\subsection{Socio-Cultural Motivations for FGM/C}

Though FGM/C is mainly practiced in African countries, it is linked more with ethnic identity than nationality (Comhlámh, 2002; UNICEF, 2005). It is an ethnic and culturally specific phenomenon, and healthcare professionals and policymakers need to be aware of the diverse meanings behind the practice in order to be able to deal with its occurrence effectively. Some broad socio-cultural and religious reasons have been identified that contribute to the continuation of the practice.

FGM/C practices took place as far back as 5,000 years ago; Egyptian mummies have been identified as having undergone the procedure (Elchalal et al., 1997; El Dareer, 1983). Historically, women have inaccurately been perceived to be predisposed to promiscuous behaviour, and this belief persists in many cultures where FGM/C is common (Muteshi and Sass, 2005). This is a particularly unwelcome trait in cultures where a woman's virginity and fidelity are closely associated with parental and familial 'honour' (Yuval-Davis, 1997). The aim

\footnotetext{
${ }^{4}$ The issue of 'medicalisation' will be discussed in more detail below.
} 
of the procedure is therefore to reduce a woman's ability to feel sexual pleasure and to seek it outside of marriage by removing her external sexual organs, especially the clitoris, and making sexual intercourse painful. Women's potential for promiscuous activities and, related to this, reproduction outside of the bonds of marriage is therefore believed to be managed and controlled via the act of FGM/C.

Performing FGM/C on girl children and women is also associated with culturally specific notions of femininity and beauty. The clitoris is believed to be the 'masculine' part of the female genitalia, and fear surrounds its potential to grow bigger than the male reproductive organs (Lightfoot-Klein, 1989). Removal of the clitoris therefore asserts women's femininity through the enhancement of socially constructed aesthetic beauty.

Apart from these issues, linked to gender stereotyped perceptions of appropriate social and sexual behaviour, women, especially in developing countries, are also disadvantaged on many other levels relative to their male counterparts (UNICEF, 2007). They may be confined to the domestic realm, and as such are in a position of economic dependence that is transmitted through generations; prior to marriage they have to rely on their fathers for survival, and upon marriage, on their husbands. Where it is socially unacceptable for men to marry women who have not undergone FGM/C, women have very little choice but to abide by this practice. In fact, other women, mothers in particular, often advocate continuance of the procedure, in order to protect the future of their daughters (El-Defrawi, 2001). FGM/C is thus viewed as a method of protection of women, in that it is believed to guard women from pre-marital promiscuity, pre-marital pregnancy, and also as a protection of their future economic survival, minimising the risk of absolute poverty, and social ostracism.

The role that women play in this practice is also strengthened by the ritual aspect of FGM/C. Though performed in private, the occurrence of this practice in some communities is marked with a ceremony celebrating the girls' transition to womanhood. It is therefore also seen as the key'rite of passage' in women's lives, and, in this sense, some communities see FGM/C as a way of strengthening the social bonds between women (Yoder et al., 2001).

Lastly, although FGM/C is also sometimes believed to be linked to religious beliefs, it is actually practiced across religions, and there are no identified religious justifications or origins for the maintenance of the practice. Although Muslims are the most likely religious group to practice $\mathrm{FGM} / \mathrm{C}^{5}$, a basis for continuing the practice is not found in the Koran. Religious leaders have denounced the continuance of the practice but the belief in its religious origins remains widespread (Al-Sabbagh, 1996).

\footnotetext{
5 Some $77 \%$ of Muslim women have at least one daughter who has been infibulated compared with $41 \%$ for Catholic women and $11 \%$ for Protestant women (UNICEF, 2005).
} 


\section{Health and Social Repercussions}

\subsection{General Health Implications of FGM/C}

As noted above, FGM/C is now considered an act of violence against women because of the physical damage that is causes, and which, if complications are not treated, can cause irreparable harm to female genitalia and reproductive organs.

\section{Immediate effects of FGM/C}

The immediate, short-term problems faced by women are death, the threat of death from haemorrhaging, and shock from the pain and level of violence associated with carrying out the procedure.

\section{Long term effects of FGM/C}

Frequent urinary tract infections, urinary retention and abscess formation, septicaemia, increased pain during menstruation, with related build up of menstrual fluid as time passes, and the development of scar tissue are some of the documented long-term side effects of the procedure (Thierfelder et al., 2005; DeSilva, 1989).

\subsection{Reproductive Health Implications}

Complications from FGM/C in the long term relate specifically to a woman's sexual and reproductive health, and as such are found to affect her roles in the community, in particular as a wife and mother. Upon marriage, women who have undergone FGM/C, particularly Type III (infibulation), will have to be 'opened' by their husbands on their wedding night, or by a midwife sometime afterward if penetration is not successful. Knives and glass are known tools used in the defibulation ${ }^{6}$ of women with Type III FGM/C (Black and Debelle, 1995). Women can also face difficulties with conception, due to associated increased risk of infection from unsanitary conditions, for example pelvic inflammatory disease and related infertility problems (Brady, 1999; Sami and El Dareer, 1983).

Labour and delivery has been found to pose significant problems for women who have the procedure (WHO, 2000). A recent study involving 28,509 women by the WHO found that "women with FGM are significantly more likely than those without FGM to have adverse obstetric outcomes. Risks seem higher with more extensive FGM" (WHO, 2006: 1835). Women with FGM/C Types I, II and III were more likely to experience the following: caesarean section, post-partum haemorrhage, extended maternal hospital stay, infant resuscitation, stillbirth or neonatal death, and low birthweight.

\footnotetext{
${ }^{6}$ The terms 'deinfibulation' or 'deinfibulated' are variations used throughout the international literature.
} 
The formation of fistulae is another health risk associated with FGM/C (FORWARD, 2007). Fistulae are holes that are created between the vaginal wall and the bladder and holes created between the vaginal wall and the rectum. These holes are usually the result of obstructed labour but FGM/C also to play a part in their formation, and they can result in permanent urinary and faecal incontinence. Some two million women in Africa, Asia and the Arab region are affected, and it is estimated that 50,000-100,000 cases develop each year (UNFPA, 2006).

\subsection{Psychological and Sexual Health Implications}

Post-traumatic stress disorder (PTSD) in both women and children who have undergone FGM/ C has been widely documented (Whitehorn et al., 2002; Momoh, 2005; Almqvist and BrandellForsberg, 1997). Behrendt and Moritz (2005) in their pilot study on 23 circumcised Senegalese women in Dakar found that the circumcised women showed a significantly higher prevalence of PTSD (30.4\%) and other psychiatric syndromes (47.9\%) than the uncircumcised women. In the instance of pregnancy, cases have been noted whereby what are seen as 'routine' procedures, for example internal examinations, can cause a traumatic flashback of the event.

Further studies by El-Defrawi et al., (2001) and by Karim (1993) found that circumcised women were statistically more likely to report psychosexual difficulties than non-circumcised women. Statistically significant difficulties were found in circumcised women to include a lack of sexual desire, less initiation of sexual activity with husbands and being less likely to experience climax (see also Khaled and Vause, 1996; Thabet and Thabet, 2001). Research has also indicated that when the clitoris is destroyed by FGM/C women compensate by 'shifting' this once most sensitive part of their bodies and instead identify their breasts as the most sensitive area (Nwajei and Otiono, 2003).

The transmission of HIV due to the unsanitary conditions and the use of un-sterile equipment also pose health risks to women and girl children who undergo the procedure (Kun, 1997). A study involving 7,350 girls less than 16 years old found that in $97 \%$ of cases, the same equipment could be used on 15-20 girls. The study concluded that the use of the same equipment facilitated HIV/AIDS and infection transmission (Mutenbei and Mwesiga, 1998; see also Morris, 1999). Moreover, the tissue trauma and lacerations inevitably associated with FGM/C leaves girls and women more likely to contract STIs in general and also HIV specifically, which is often very widespread in the areas in question (WHC, 2006). Research over the past 10 years has correlated dirty cutting equipment, haemorrhages requiring blood transfusion, and injurious sexual intercourse causing vaginal tearing and lesions with rising rates of HIV transmission among women in countries where FGM/C is still widely practised (IPPF, 2007). 


\subsection{Counterproductive Social Repercussions}

The negative implications of FGM/C also extend to the social realm. It has already been noted that women without the procedure risk being outcasts in their communities. It should also be noted that some related health consequences might also cause a woman to be rejected. For example, the majority of women who develop fistulae are abandoned by their husbands because of their inability to have children, and ostracised from their communities because of their foul smell (UNFPA, 2006). Fistula formation is sometimes a recognised ground for divorce, and causes a lack of marriageability, therefore, FGM/C can have the opposite effect of what it sets out to achieve.

Male complications from FGM/C have also been documented; Almroth et al., (2001) report that men experience problems such as difficulty with penetration and associated pain, and the development of wounds and/or infections to the penis. Related psychological problems were also found in that men were concerned about inflicting pain upon their wives. The men also discussed problems after reinfibulation, and the associated medical care costs. A study that included 30 grandfathers and 29 young men, where all but one were married to infibulated women, found that none of the male respondents cited positive health effects from the FGM/C (Adams, 2004). The key finding was that the men involved sympathised with the suffering their wives endure because of $F G M / C$, and regretted their contribution to that suffering.

What these and previous studies highlight is a fundamental disjuncture between the reasons why FGM/C is practiced and what it often eventually achieves. While its aims are to enhance a woman's desirability as a wife and sexual partner, the real outcomes of FGM/C disadvantage women in precisely the areas where it is supposed to protect and empower them:

marriageability, sexual relationships and fertility. Hence, FGM/C does not function effectively in its desired outcomes, and represents a harmful practice rather than a protective endeavour. 


\section{The Health Sector Response}

\subsection{Horm Reduction vs. Erodication}

Because of all the potential negative health consequences outlined above, there has been a shift from familial and community based FGM/C towards the medicalisation of FGM/C (Bosch, 2001).

Medicalisation of FGM/C refers to the act of maintaining the physical and aesthetic aspect of the mutilation, but for the procedure to be carried out in sanitary and sterile settings by medical professionals. In doing so, the principle is held that the risks to the health and lives of women and children are removed and respect for cultural difference is maintained as a result (Valderrama, 2002). Shell-Duncan calls for the implementation of medicalisation as a harm reduction strategy representing "a sound and compassionate approach to improving women's health in the settings where abandonment of the practice of 'circumcision' is not immediately attainable" (Shell-Duncan, 2001: 1013). The author views the practice of medicalisation of FGM/C as a temporary transitional compromise.

Yet this does not take into account the practical implications of such an approach. Medicalised procedures would only be available to the more affluent members of societies, thus posing serious equity of access questions. The training of Traditional Birth Attendants and midwives in the use of various anaesthetics has also been advocated by harm reduction campaigners. This, too, would be impractical on the basis that national training programmes would have to be implemented, reducing the level of available funding for other medical necessities. The promotion of the medicalisation of FGM/C would also send out a mixed message as to governments' real commitment towards the eradication of this practice.

In relation to medical practitioners, the United Nations adheres to the position of ending violence against women and, as such, objects to any measures that would imply medical approval of the procedure on any level. "The involvement of medical professionals in the practice, in fact, undermines the message that FGM/C remains a discriminatory act of violence that denies women and girls their right to the highest attainable standard of health and physical integrity" (UNICEF, 2005: 13). The practice has, in fact, been generally rejected by the medical profession internationally on moral and ethical grounds, as it violates the Hippocratic Oath and therefore cannot be seen as an alternative to the traditional practice of FGM/C. 


\subsection{Culture, Health and Gender}

The issue of medicalisation above highlights a key area of debate that often affects the provision of care for ethnic minorities in general, and especially ethnic minority women, that of cultural relativism. Cultural relativism is "the doctrine that everything is relative and if you truly understand a culture you will also appreciate the function of behaviours that might otherwise appear cruel, discriminatory or offensive" (MacLachlan, 2006: 213). However, it may be better to accept that, depending on your perspective or context, all cultures have some bad things about them, and also that cultures are dynamic social systems and in order to survive they must adapt to new environments. In other words, cultural relativism should not be used to justify practices that negatively impact on women's health and wellbeing, even if this means questioning tradition (Meleis, 2003).

Some argue that FGM/C is not perceived universally as a psychologically damaging form of violence within the social and cultural context in which it occurs (Black and Debelle, 1995). However, this position has now been widely disputed while FGM/C is internationally firmly recognised as a human right abuse and a form of gender-based violence. The Convention on the Elimination of all Forms of Discrimination against Women (CEDAW), Article 5a, specifically stipulates that internationally, nations should take all appropriate measures:

"To modify the social and cultural patterns of conduct of men and women with a view to achieving the elimination of prejudices and customary and all other practices which are based on the idea of the inferiority or superiority of either of the sexes or on stereotyped roles for men and women."

Nevertheless, it is crucial that health professionals and other anti-FGM/C campaigners in non-practicing countries retain a reflexive stance when advocating for the eradication of this tradition. Conroy (2006) has pointed out that the circumcision of women was a common, medically promoted activity to cure a variety of psychological and marital ills as recently as the early twentieth century in the West. He also noted that procedures aimed at conforming to cultural gendered ideals of beauty and desirability, such as breast augmentations and vaginoplasty ${ }^{7}$ are also increasingly common in Western countries. While this argument is not sufficient to condone FGM/C, which has been recognised as a human right abuse because of its significant long-term harm to women and being carried out without consent mostly on children, it does emphasise the need to be aware of the less appealing aspects of one's own culture as well as that of others.

\footnotetext{
${ }^{7}$ Vaginoplasty is a surgical procedure designed to tighten a woman's vagina, by removing excess lining and repairing the surrounding soft tissues (http://www.cosmeticsurgery.com/research/cosmetic-surgery/Vaginoplasty/ accessed on 24.08.07)
} 


\subsection{Culturol Competence in Treatment}

While women in the most affected areas will continue to struggle to access appropriate care for the physical and mental health consequences of FGM/C, efforts are taking place in countries of immigration to provide care to them when they present to health services there. However, health service providers in these countries, including Ireland, are also faced with particular challenges and dilemmas.

In general terms, it is vital that all health service providers are trained in the area of 'cultural competence.' This will allow them to provide appropriate health care being sensitive to ethnic and religious minorities' needs without falling into the pitfalls of cultural relativism, as examined above. Moreover, those involved in the care of women who have experienced gender-based violence, including FGM/C, need to be particularly sensitive and flexible to these women's needs (WHC, 2006; AkiDwA, 2002). Past research has indicated that the key barriers and areas of concern for women with FGM/C in accessing culturally competent care include:

- $\quad$ Language barriers particularly during stressful experiences/procedures, such as childbirth (McMeel, 2005; NCCRI, 2007; Munro, 2005).

- $\quad$ Use of inappropriate terminology when referring to FGM/C which does not mirror women's own understanding of the procedure ${ }^{8}$ (Mwangi-Powell, 2001b; Royal College of Midwives, 1998).

- $\quad$ Insufficient knowledge on the part of the healthcare provider regarding the motivations for FGM/C and its subsequent treatment (Toubia, 1999; Denholm, 1998).

- $\quad$ Lack of familiarity with mutilated female genitalia limiting the ability of health professionals to treat the condition promptly (Munanie, 2001).

- $\quad$ Lack of availability of female healthcare professionals when requested (Mwangi-Powell, 2001a).

- $\quad$ Lack of awareness in relation to national legislation and the potential risk of FGM/C after the birth of female babies to women from communities known to uphold this tradition.

- $\quad$ Lack of codes of conduct when in contact with FGM/C and a lack of knowledge of its implications for treatment (Jager et al., 2002).

Momoh et al., (2001) outline that when healthcare professionals come into contact with women from FGM/C practicing countries, they should ask them directly if they have been 'cut' as most women do not usually volunteer this information; it also takes the onus off of the woman.

\footnotetext{
8 The woman may, for example use the term 'closed' instead of the medical term 'infibulated', or she may use the term 'cut' instead of 'mutilated'.
} 
A number of health care issues arise in relation specifically to childbirth. In some cases FGM/C Types I, and II do not necessarily lead to, or require medical intervention at this time. However, reversal of Type III FGM/C is medically necessary and legally acceptable; nevertheless closing the area to restore the infibulated state after delivery is against medical ethics. Despite this, it may occur, and studies have shown that the reinfibulation procedure has been carried out in countries where it is illegal because the professional in charge of the woman's care is not aware of FGM/C legislation and its implications for ethnic minority women's healthcare (Thierfelder et al., 2005).

Furthermore, reinfibulation has been performed out of a well intentioned, but misguided act of respect for cultural difference (Ibid). In other cases, caesarean sections have been used as an alternative to the defibulation/reinfibulation issue (Vangen et al., 2004). Defibulation is most commonly performed during the second stage of labour. However it is recommended that defibulation occur antenatally, so as to avoid a situation during labour where the professional may not be familiar with the necessary treatment (McCaffrey et al., 1995). The success of defibulation for the restoration of women's anatomy is in some cases as high as 60 per cent, with all functions being restored (Jones, 2000).

Looking at this issue from a woman's perspective, a study of Eritrean women who gave birth in Sweden, Lundberg and Gerezgiher (2006) found that their participants had six main concerns prior to birth - fear and anxiety, extreme pain and long-term complications, healthcare professionals' knowledge of circumcision and the health-care system, support for family, relatives and friends, defibulation and their decision not to have FGM/C performed on their daughters. A further concern identified in the literature was that of being different to other women on two levels, women with FGM/C may identify a difference between them and women resident in the host country, yet they may also perceive a difference once their FGM/C status has been reversed, in relation to other women whose FGM/C status has not been reversed, and because of this, counselling services would be beneficial (Leye et al., 2006; Muecke, 1992; Sansani, 2001). Health service providers will need to be aware of all of these issues in order to provide appropriate and comprehensive treatment for women affected by $\mathrm{FGM} / \mathrm{C}$. 


\section{Strategies for Change: Prevention and Eradication}

While the provision of continued and informed care for women who have been affected by FGM/C is crucial, the key to improving the health and lives of women at risk rests in the numerous prevention and eradication strategies that have been implemented worldwide in an attempt to bring the practice of FGM/C to an end (Lewnes, 2005). Some have proven more effective than others (WHO, 1999; Wabaki, 2007). While legal and political measures, which will be explored below, are fundamental to ending FGM/C, community based eradication and prevention initiatives in conjunction and consultation with NGOs have now become a key component of campaigns worldwide. "While government action is necessary to create a political and legal environment that deters people from practicing $\mathrm{FGM} / \mathrm{C}$, it is ultimately the women, their families and their communities who must be convinced to abandon the practice" (Rahman and Toubia, 2000: 73).

There are six main approaches undertaken to end FGM/C:

1. Alternative Symbolic Rituals (ASR's): Symbolic ceremonies that do not harm the body.

2. Risks to Health Approach: Health workers as key agents advocating for change emphasises the risks to health from FGM/C. However it should be noted this approach has also influenced the increased medicalisation of the practice by some communities (RAINBO, 2004).

3. Human Rights: Emphasises FGM/C as a violation of the universal human rights of women and children.

4. Provision of reproductive information and educative materials that empower women - Community Based Eradication.

5. Positive Deviance: whereby influential individuals in the community publicly declare their opposition to the practice, and work to influence others to do the same (McCloud et al., 2003; West, 2003; Jabre et al., 2007).

6. Directly targeting excisors/Traditional Birth Attendants and helping them to find an alternative source of income (Population Reference Bureau, 2005).

This review focuses on two prevention approaches that could be potentially successful in Ireland. Thus the approaches examined are discussed in the context of implementation in a country where the community in question is a migrant ethnic minority. However, all these approaches are complementary and a strategy that takes into account localised meanings and needs is necessary for its successful implementation in any setting. 


\subsection{Community Based Erodication}

Community based eradication programmes are implemented based on the principle of positive cultural change by empowering all members in the community to work together for long-term development (Chege et al., 2001; Chege, 2004). It employs a holistic approach rather than one that focuses specifically on the effects on health (UNFPA, 2004); although promoting health and well-being remains a key aim. The potential success of a community based approach is evident from the situation in Senegal, where when 31 villages publicly declared their denouncement and abandonment of the practice, the national government responded by outlawing FGM/C (Tostan, 1999). Community based strategies emphasise that communities must own the approaches to overcoming harmful traditional practices; NGOs and governmental bodies should, however, play a part in the facilitation of this process (Watt and McGaughey, 2006).

Community based prevention/eradication strategies for FGM/C can be characterised as those which aid communities in the following:

- $\quad$ Recognition of the problem.

- $\quad$ Identification of key community representatives and stakeholders (women, husbands, religious leaders, young adult females).

- $\quad$ Identification of divergent meanings associated with the practice amongst groups.

- $\quad$ Identification of individual and shared needs within the (ethnic minority) community.

- $\quad$ Promotion of long-term sustainable goals for women and children's health (Figueroa et al., 2002) ${ }^{9}$.

Any community based initiative to either prevent or eradicate FGM/C must begin by empowering women to become the key 'agents of change' (Rajadurai and Ingras, 2005), as it has been recognised that women can be resistant to eradication efforts (Toubia and Sharief, 2003). Aiding women as the principal stakeholders in the process also contributes towards the establishment of gender equality within what are usually identified as arenas of gender inequality - sexuality and reproduction (Lightfoot-Klein, 1991, Lightfoot-Klein, 1989). At the same time men have been found to promote and embrace the idea of cultural growth within communities; this aspect of eradication and prevention should also be welcomed and utilised fully (Ouoba, 2003; Habtemariam et al., 2003).

\footnotetext{
${ }^{9}$ A more detailed model for social change to stop FGM/C is provided in Appendix I.
} 


\subsection{Alternative Symbolic Rituals}

As noted above, the tradition of FGM/C often represents a means of social bonding for women and their community. It often provides the opportunity for great celebration and giftgiving within communities contributing to increased social cohesion (BAFROW, 1999). The Alternative Symbolic Ritual (ASR) approach recognises these aspects of traditional practices and seeks to turn harmful cultural practices, based upon notions of gender inequality into functional acts that contribute to cultural growth and social cohesion, whilst not being to the detriment of women's health (Muteshi and Sass, 2005). Hosken (1993) further outlines:

"It is much more productive to develop new activities to take the place of damaging customs than to prohibit outright what has been done traditionally. The alternative proposed here is to change the contents, stopping the mutilations while preserving the positive idea" (cited in Baumgarten, 2001: 27).

The development of Alternative Symbolic Rituals can become a platform for open debate and discussion amongst men and women within ethnic minority communities establishing in a new country. It ensures that the group does not feel challenged by society, but instead empowered to make necessary changes to harmful traditions (Lisy, 2007). Alternative Symbolic Rituals have been found to be an effective approach to the eradication/prevention of FGM/C. The approach is developed in three phases:

1. Community sensitisation.

2. Seclusion of girls for life-skills education.

3. Community celebration of the girls' new status as young women (Muteshi and Sass, 2005).

The seclusion of girls is an essential aspect of the ASR approach as it mimics the recovery period girls usually go through post FGM/C. However, the seclusion period associated with ASR is beneficial to women and girl children because it is a period where girls learn about women's health. It is also about the improvement of social skills and related abilities of girls to resist pressure from others who may advocate FGM/C (Baumgarten, 2001; Masterson and Swanson, 2000). The final stage of the ASR is to conduct a celebration that involves all members of the community. The importance of ASR is that it takes a tradition usually conducted by women, that is hidden and shrouded in secrecy and places it into the public realm from the initial stage of consultation with key community members, to seclusion of girls for life-skills education, and finally to public acceptance and celebration of cultural growth working towards, ultimately, the goal of gender equality (BAFROW, 1999). 


\section{FGM/C: Legislative Policies}

It is desirable that the community based actions for the eradication and prevention would take place within a legislative framework governing FGM/C. Many countries already have legislation in place that is either FGM/C specific or can be invoked in instances of FGM/C. For examples, a recent case in Spain saw a Gambian father seeking legal protection for his daughter regarding an impending FGM/C procedure advocated by the child's mother. He contacted a judge who invoked The European Charter on Children's Rights (2001) to prevent the child from traveling from Spain to the Gambia under the guise of a holiday to undergo the procedure (Pellegrino, 2007). While this case exemplified the effectiveness of ongoing campaigns to raise awareness on the dangers and harm caused by FGM/C, it also highlights the crucial role that legislation plays in this area.

Multiple legal measures, both nationally and internationally have been developed and implemented in a concerted attempt by governments and policymakers to eliminate violence against women, including its manifestation in the form of FGM/C. This section briefly outlines some of the legislative developments in Africa and Europe. Although most legislation will have the aims of both eradication and prevention, the African legislation is more focused on eradication, while the European cases are more focused on preventing the tradition becoming established. The legal advances made in the attempts to eradicate FGM/C highlight the opportunities but also the challenges that lie ahead for the Irish government, policymakers and medical institutions.

\subsection{Africa}

Africa signified its commitment to the eradication of all forms of violence and inequality against women at legislative level on 11 July 2003 when 28 governments signed The Maputo Protocol at the Second Ordinary Summit of the African Union. To date there are 43 signatories of the Protocol: of which 21 countries have ratified the Protocol, 25 states have signed but not ratified it; and 7 countries have not signed it ${ }^{10}$. The Protocol calls for the adoption and implementation of policies at national level that make a dedicated and concerted effort to:

- $\quad$ Protect women from all forms of violence whether sexual or verbal, and whether in public or in private.

Generally prevent, punish and eradicate violence against women.

- $\quad$ Eradicate elements and stereotypes in traditional and cultural beliefs, which legitimise and exacerbate violence against women (Njoroge, 2005).

\footnotetext{
${ }^{10}$ See Appendix II for further details of signatory of this convention and specific African national laws.
} 
In reference to FGM/C, Article 5(b) of the Protocol also outlines that it condemns "female genital mutilation, scarification, medicalisation and para-medicalisation of female genital mutilation" (African Union, 2003: 8). The Protocol outlines that states should put in place counselling services for women who require them - recognising the long-term traumatic effects suffered by women because of gender based violence. Provision is also made within the Protocol for individuals other than the victims themselves to make a complaint on behalf of the victim, if for whatever reason they do not feel able to make a formal, official complaint themselves. In countries that remain outside the Protocol governments have preferred to emphasise the grass roots approaches described earlier rather than inter parliamentary legislation.

\subsection{Europe}

The response to the advent of FGM/C within European borders has been primarily one of legislating to prevent FGM/C becoming an established practice, perpetuated and continued on the basis of culture (Miller, 2004). European Union policy and legislative developments have recognised that the practice of $F G M / C$ is a clear violation of a multitude of human rights declarations. The practice is perceived to bring with it personal, health and social implications that contravene established legislation within the EU, in particular those related to the right to physical autonomy and bodily integrity (EU, 2000).

The Council of Europe rejects a 'cultural relativist' approach to FGM/C, as outlined in Resolution 1247 (2001), which argues that governments should implement specific legislation to prohibit FGM/C whilst also developing and implementing a system whereby all immigrants to Europe are made aware of legislation that bans the practice. In particular in Article iii, the Resolution explicitly emphasises that European governments should "adopt more flexible measures for granting the right of asylum to mothers and their children who fear being subjected to such practices" (Council of Europe, 2001).

Under EU declarations and guidelines, national governments have been advised to develop legislation outlawing FGM/C, taking into account the social, demographic, medical and historical context of each society (Poldermans, 2006). Miller (2004) outlines three broad categories of national strategies in legislating for $F G M / C$ prevention within the EU countries that can be characterised by an approach which:

(a) Enacts specific legislation that criminalises the practice;

(b) Modifies existing legislation to make specific reference to FGM/C; or

(c) Prohibits the practice under general laws already enacted. 
The approaches taken by a number of European countries are outlined here. The legislative policies in place in Sweden, France and The United Kingdom have been deemed effective in FGM/C prevention in a European setting.

\section{Sweden}

Sweden became the first European country to legislate specifically against FGM/C in 1982, and has been noted for its proactive stance in reaction to the practice at a time when a relatively small numbers of immigrants were in the country (Leye and Deblonde, 2004). However, Sweden's interpretation of FGM/C has been criticised as being too broad, and raising questions for those who implement specific legislation against FGM/C - "the Swedish Act on FGM technically outlaws genital changes also in non-African women, and all gynaecologists or plastic surgeons performing such alterations to the genitalia for non-medical reasons could be prosecuted" (Leye and Deblonde, 2004: 10).

\section{France}

Although France did not enact specific FGM/C legislation it did recognise the harm associated with the practice and maintains an active, watchful stance on the prevention and elimination of all forms of FGM/C within French society in general. Under Penal Code 312, acts of harm such as mutilation are punishable by up to 20 years imprisonment in the case of death of the victim (Poldermans, 2006). The government also adheres to the principle of extraterritoriality ${ }^{11}$, which provides protection against the practice being purposely performed outside of the immediate jurisdiction of France in a country where the practice remains legal.

The legislation is further complemented by the use of preventative measures at local level. For example,' 'Protection Maternelle Infantile' Centres (Maternal and Child Healthcare Centres) (Leye and Deblonde, 2004), are instructed to carry out a systematic inspection of the external genitalia of all girls and report cases of suspicion of FGM/C. In the context of a suspicion of a future crime of FGM/C, cases are reported to judicial authorities. This measure is in place in a concerted effort to prevent what are referred to as FGM/C 'holidays' in the ethnic country of origin where FGM/C procedures are still routinely practiced. France has also been the most active European country in pursuing criminal procedures against those responsible for continuing the practice, though the number is relatively small, with only 35 cases presented before the courts thus far (Poldermans, 2006).

11 Extraterritoriality therefore provides a legal measure that sees nationals/citizens of France bound by the legal repercussions set forward with regard to the practice of FGM/C regardless of the geographical location in which it occurs. 


\section{United Kingdom}

A recent statistical report suggested that in the UK possibly 5,444 girls under 16 years are at risk of FGM and 69,875 women are already affected (Leye and Deblonde, 2004). FGM/C is governed by the Prohibition of Female Circumcision Act, 1985, and specific legislative steps have been taken to ban the practice within the UK jurisdiction. The Act specifies that infibulation is an offence regardless of who performs the procedure. However, subsection (1 A) of the Act does take into account that operations medically necessary may be carried out by a registered medical practitioner. This is to ensure that women who have been infibulated may be surgically defibulated in order for the final stages of labour to progress naturally, preventing the need for caesarean sections. Further legislative measures were taken in 2003 with the enactment of the Female Genital Mutilation Act in England, which added the principle of extraterritoriality and increased the term of imprisonment from 6 months to 14 years (Leye and Deblonde, 2004) ${ }^{12}$.

\section{Concluding Comments on Legislation}

This brief overview shows that different approaches have been taken in different countries. To be effective, the legislative frameworks must be properly thought out and cognisant of the various medical and social implications of FGM/C. However, regardless of the legislative approach taken, $\mathrm{FGM} / \mathrm{C}$ prevention may be difficult as it may become hidden when criminalised. This secretive nature is also compounded by the fact that FGM/C is an intergenerational act performed within and throughout the family (Leye and Deblonde, 2004). Those who practise it must therefore be provided with the educational, social and economic tools to develop alternative cultural norms that are not harmful to women. The enactment of legislation is therefore a necessary but not sufficient element in a broader strategy towards FGM/C eradication (National Council for Childhood and Motherhood Egypt, 2003).

\footnotetext{
12 Scotland enacted The Female Genital Mutilation Act in 2005.
} 


\section{FGM/C in Irelond}

Within an Irish context, the presence and possible occurrence of FGM/C is a relatively new phenomenon (Donnelly, 2001; Mutwarasibo and Smith, 2000), linked to recent immigrant and increased ethnic diversity ${ }^{13}$. Some instances of FGM/C in Ireland have been reported, with a consultant at a major national maternity hospital citing one case per week (Donnelly, 2001); however, very little information is available on its incidence and prevalence nationally. Because of its recent appearance, we are also at an early stage of learning how to treat women who have undergone this form of violence and cruelty (SPIRASI, 2007). Continued inward migration to Ireland necessitates that the Irish healthcare system becomes proficient at dealing effectively with the short and longterm consequences of FGM/C for women, and in particular the implications for childbirth. Providing guidance to health professionals in this sensitive area through the development of a national protocol to deal with women affected by the practice would represent a first step towards a best practice model.

In light of the increased intercultural profile Ireland has the unusual but valuable opportunity to be proactive in the prevention of $\mathrm{FGM} / \mathrm{C}$, rather than being in a reactive position of having to deal with the more problematic eradication of a practice already established in a new context (NCCRI, 2007). This should be done in a manner that is sensitive to cultural diversity yet gives priority to the needs of women affected on social, physical, and emotional levels by the continued practice of FGM/C (Lentin and McVeigh, 2006; Tomkin, 1999; Sansani, 2001).

Health professionals nevertheless might find themselves in a challenging position in relation to requests to perform FGM/C. Refusing the procedure has the potential to push the practice underground, thus hiding it from both authorities and the health system (DoHC, 2006; Powell, 2004). However, as seen earlier, the practice must not be embraced by the medical profession on 'safety' grounds. Again, their role lies in highlighting the risks of the practice and explaining why it is not available in Ireland to those who might request it for their daughters. It is therefore very encouraging that the Irish Medical Organisation recently called for improved legislation in this area and has urged doctors to report suspected cases of FGM/C to the authorities (Irish Medical News, 2007).

\subsection{Legislation in Irelond}

While prevention initiatives are important, it is also necessary to ensure that Ireland has the appropriate legislative framework to criminalise the practice of FGM/C. At present no cases of alleged or confirmed FGM/C have been brought to the attention of either the Gardai or the Director of Public Prosecutions ${ }^{14}$. It would appear that legal measures dealing with the occurrence of FGM/C are to

13 The most recent Central Statistics Office figures of the population classified by 'religion and nationality' indicate that a total of 35,326 respondents cited 'Africa' as nationality, while 46,952 respondents cited 'Asia' as place of origin. These figures, however are likely to be underestimates due to the voluntary nature of participation in the Census (2006).

14 Personal communication with the DPP on 5 October 2006 and with An Garda Síochána in January-February 2007. A prosecution did take place in Waterford in 2005 following the death of a male infant. However, the jury in that case acquitted the defendant following a charge from the judge, which appeared to accept that different standards might be application to immigrant communities. This case led to the establishment of the Committee on Male Cultural Circumcision that has since recommended that circumcision for male infants be provided in the Irish health service (DoHC, 2006). 
be found under the Non-Fatal Offences against the Person Act, 1997. Though not originally intended to incorporate FGM/C, the Act is a general measure aiming to criminalise intentional harm to others ${ }^{15}$. However, under further scrutiny, it appears that this legislation would be ineffective in the prosecution of FGM/C due to its cultural relativist approach, as outlined in Article 3:

"No such offence is committed if the force or impact, not being intended or likely to cause injury, is in the circumstances such as is generally acceptable in the ordinary conduct of daily life and the defendant does not know or believe that it is in fact unacceptable to the other person".

Scope for argument regarding 'ordinary daily conduct' is wide, if the defendant can put forward the case of being unaware that such prohibitions are legislated for in Ireland or that 'ordinary daily conduct'for them includes cultural practices that may harm others. The defendant could also argue of being unaware that the practice would be unacceptable to the other person because of shared cultural tradition. Owing to these loopholes, a Bill to Prohibit Female Genital Mutilation (2001) was proposed as a means to specifically legislate against FGM/ $\mathrm{C}$ in Ireland. Under its terms, however, it would have been acceptable for a member of the medical profession to prove that a surgical procedure on a woman's genitalia was a medical necessity to safeguard her life or health. However, the Bill was rejected on the basis that the Non-Fatal Offences against the Person Act, 1997 was considered to be an adequate legal tool. Since then no further legislative efforts have taken place. The WHC therefore wishes to call for either the introduction of a specific bill prohibiting FGM/C and outlining penalties for those who perform it, while allowing necessary surgical interventions, or the amendment of the current legislation to ensure that a cultural relativist interpretation or the upholding of cultural traditions are not valid grounds for defence.

\section{Immigration Legislation}

The impact of FGM/C must also be considered when considering requests for asylum. Some women, who cite risk of FGM/C as a basis for asylum or refugee status, or have undergone the procedure, come to Ireland out of fear for themselves and/or their daughters (ICCL, 2000; Pillinger, 2007). Cases for asylum have, however, been rejected on the basis of the country of origin being declared as a'safe country of origin' in relation to FGM/C ${ }^{16}$. Currently, Irish authorities can reject applications for refugee status on the basis of gender violence, as 'gender' is not categorised as a basis for protection in the United Nations Convention on the Status of Refugees, 1951 (ICCL, 2000). This situation must also be rectified in light of the international recognition of FGM/C as a human right abuse. It is also essential, for Irish policymakers to be familiar with national and international legislation regarding FGM/C and women's rights in general, when considering the cases of women asylum seekers.

15 'Harm' defined within the Non-Fatal Offences against the Person Act, includes harm to the body or mind of others. 'Serious Harm' is also defined, as being harm that is injurious to the extent to pose a significant threat to another persons life.

16 For example, see I. \& Ors v. MJELR [2008] IEHC 23. See also Minister for Justice, Equity and Law Reform, Dáil Debate, Dáil Eireann, Vol. 616, 9 March 2006. 


\section{Conclusions and Recommendations}

Female Genital Mutilation/Cutting is internationally recognised as a form of violence against women and an act that ensures the continuance of gender inequality (UNIFEM, 2003). This has been officially endorsed by the UN (UNIFEM, 2003) and the African Union (2003).

A low incidence rate would imply that Ireland is currently in a favourable position to maintain a preventative and simultaneously a protective position in relation to women from ethnic minority groups settling or seeking sanctuary in Ireland. Ireland is also in a position to protect future generations of girl children born in Ireland from undergoing this procedure.

In light of the issues explored through the international research above this review concludes by outlining some key recommendations.

An intergovernmental working group should be established to tackle the issue and coordinate the actions outlined below.

\section{Health Sector Recommendations:}

The Medical Council and An Bord Altranais should review their guidelines to prohibit FGM/C and to give guidance on how to treat women already affected by FGM/C. Health professionals, and especially those involved in obstetrics and gynaecology, should be trained in the types of treatment most appropriate for FGM/C affected women and children.

Availability of expertise in this area should be widely publicised so that referrals can be made without delay.

Adequate provision of interpreter services should be established in healthcare settings, particularly those dealing with women's health to ensure full communication is facilitated at all times.

Modules in gender and culture should be compulsory on all medically orientated undergraduate degree courses. 


\section{Prevention Recommendations}

An approach to prevention and behaviour change should be implemented at the community level, and a needs assessment undertaken to identify the prevalence of FGM/C in Ireland.

- Women should be identified and enabled to work as role models against FGM/C in their communities and influence others to do the same.

- $\quad$ Key religious and community leaders should be consulted at all stages of collaboration; their public denouncement of FGM/C is essential for eradication/ prevention of the practice to be successful.

- $\quad$ Adequate, sustained funding is an essential aspect to enable this process of prevention and behaviour change. It also signals a genuine commitment by those in authority to the health and welfare of ethnic minority groups in Ireland.

- $\quad$ Social Workers and the Gardai should receive training to aid in the prevention of FGM/C becoming an issue for child protection in Ireland.

- Teachers of primary and secondary school aged children should also be informed as how to identify or report suspected cases.

- $\quad$ Information should be provided to women and their families (in their first language) at their point of entry to the Irish state in relation to the State's position on the practice of FGM/C.

- $\quad$ Adopt best practice models employed elsewhere for community based prevention and eradication.

\section{Legal Recommendations:}

Specific legislation similar to the previously proposed Act to Prohibit Female Genital Mutilation (2001) should be enacted in order to provide legislative protection to women facing FGM/C. The enactment of specific legislation is also necessary to ensure that the medical profession are enabled to provide necessary medical treatments and/or interventions.

If this is deemed unfeasible, current legislation must be amended so that it does not allow scope for interpretation that advocates a culturally relativist approach. Furthermore the principle of extraterritoriality should also be implemented as an extension of national legislative protection. 


\section{Research and Information Recommendations:}

- Statistics should be collated on women presenting to services who have undergone FGM/C. Primary care as well as reproductive and sexual health services should be targeted for data collection.

- $\quad$ In relation to the collection of hospital data, the Council suggests the Economic and Social Research Institute consider the use of the code for FGM/C and its systematic application.

- $\quad$ Statistics should be also collated on any new cases of FGM/C deemed to have taken place in Ireland. This would require a focus on primary and paediatric care, as well as any presentations at emergency services.

Overall, any strategy tackling an issue such as FGM/C must take the dual approach of legislating against the practice at a national and international level, and empowering and educating people at the local level so as to bring about the eradication of this practice.

In an Irish context perhaps the most important task, after establishing an adequate legislative framework, is to ensure that the practice does not become established among migrant ethnic communities, and that those charged with service provision, in particular in the health system, are equipped with the appropriate training and information to deal with FGM/C if and when they encounter it. 


\section{Appendix I:}

\section{Women's Empowerment Community Consensus - WECC}

Model for Behaviour Change [Adapted from Toubia and Sharief, 2003: 259]

\author{
Step 1: Conduct a Situational Analysis
}

\section{Step 2: Access the Community}

Step 3: Choose Project Inputs

Step 4: $\quad$ Reach Target Groups
- The cultural context of FGM

- Current types and ages

Current social and political environment

Base-line data on prevalence and stages of behaviour

- Build community trust and acceptance Identify means of reaching women and girls

A) Develop appropriate messages

- Reproductive health Information

- Health risks of FGM

(physical, mental and sexual)

- Position of religion

- Women's and children's rights

- Effect of FGM on girls education

- Effect on family life

- Legal risks

B) Choose women's empowerment inputs

- Literacy, organizing and problem solving skills

- Income generating and marketing skills

- Introduction of laws and policies

- Provide reproductive health services

- Primary

Women and girls

- Secondary

Men, community leaders, religious leaders,

circumcision providers,

media, policy makers, health and legal professionals 
Step 5: Move to Decision Stage

Step 6: Ensure Maintenance

Move More to Decision Stage

Other Outcomes

\section{PUBLIC DECLARATION}

- Re-enforce messages

- Support groups

- Voluntary reporting

- Reaching end points

- Continue inputs

- Cultivate local leaders

- Incorporate social change into permanent institutions

- Improved status of women

- Improved reproductive health 


\section{Appendix II:}

\section{African Countries Legislative Approaches}

\section{Table 2}

Signatories to the Maputo Protocol

(No Peace Without Justice, 2007)

Ratified and Signed Tanzania, Burkina Faso, Zambia, Seychelles, Mozambique, Benin, Mauritania, Togo, Cape Verde, Gambia, Malawi, Djibouti, Mali, Senegal, South Africa, Nigeria, Lesotho, Namibia, Rwanda, Libya, Comoros

Signed but not ratified Algeria, Angola, Burundi, Cameroon, Chad, Cote d'Ivoire, Congo, Democratic Republic of Congo, Equatorial Guinea, Ethiopia, Gabon, Ghana, Guinea-Bissau, Guinea, Kenya, Liberia, Madagascar, Mauritius, Niger, Sahrawi Arab Democratic Republic, Sierre Leone, Swaziland, Somalia, Uganda, Zimbabwe

Not ratified

Botswana, Central African Republic, Egypt, Sao Tome é Principe, Sudan and Tunisia

Specific legislation with regard to individual states in Africa varies from those who do not have any developed legislation for FGM/C (Eritrea, Ethiopia, The Gambia, Liberia, Nigeria, Sierre Leone, Somalia) to those who have implemented legislation but with varying degrees of effectiveness (See Table 3). 


\section{Table 3}

\section{Examples of African National Legislation}

(No Peace without Justice, 2007; Development Gateway Foundation; Cook et al., 2002)

Benin

Medical institutions are obliged to give assistance to victims and have an obligation to report incidences of FGM/C to the authorities.

Djibouti The penal code stipulates that 'acts of violence resulting in Genital Mutilation' are punishable up to 5 years imprisonment, but it does not make specific reference to Female Genital Mutilation, nor does the law define the act itself.

Kenya

Legislation covers the effects of mutilation that 'negatively affects' children. Here, the law is simultaneously weakened by the use of the term 'negatively affect'.

Togo

Article 5 stipulates that'all persons who perform FGM whether in the traditional or modern set up will be punished for intentionally causing harm!. The law furthermore requires that public and private hospitals must assist victims of FGM/C if they present themselves on site. The emphasis of the Togo government is to prevent the medicalisation of the practice whilst ensuring medical assistance to victims.

Cameroon

There is no specific law criminalising the practice, but the country has signed up to many of the international treaties that aim to overcome it via other means.

Egypt

A ministerial decree in 1996 prohibits the practice. The Cairo Declaration for the Elimination of FGM was also signed in 2003. However, Egypt has mainly focused on community based approaches, perceiving these as being the most valuable in advocating for effective behavioural and social change in the long term. In recent times, the death of 12-year old girl as a result of a medically performed FGM/C has led to a complete ban on the practice, to include medicalised procedures. 


\section{References}

Abbas, M. (2006) 'Female Genital Mutilation: The Facts' in Irish Medical News, pp. 46.

ACCM (2004) FGM Conference, Cardiff, 17th June 2004. www.accmsheffield.org accessed on 24/04/2007.

Adams, K. (2004) 'What's "Normal"? Female Genital Mutilation, Psychology and Body Image' in Journal of American Medical Women's Association, 59 (3), pp. 168-70.

African Union (2003) Protocol to the African Charter on Human and Peoples Rights on the Rights of Women in Africa (Maputo Protocol).

http://www.africaunion.org/root/au/Documents/Treaties/Text/Protocol\%20on\%20the\%20Rig hts\%20of\%20Women.pdf

AkiDwA (2002) Submission on the National Action Plan against Racism in Ireland. Dublin: Islamic Cultural Centre of Ireland - (ICCI) Women's Project.

Almroth, L, et al., (2001) 'Male Complications of Female Genital Mutilation' in Social Science and Medicine, 53(11), pp. 1455-60.

Almqvist, K, and Brandell-Forsberg, M. (1997) 'Refugee Children in Sweden: Post-Traumatic Stress Disorder in Iranian pre-school children exposed to organised violence', in Child Abuse and Neglect, 21, pp. 351-366.

Al-Sabbagh, M.L. (1996) The Right Path to Health, Health Education Through Religion: Islamic Ruling on Male and Female Circumcision. Egypt: World Health Organization.

BAFROW (1999) Rites of Passage: Responses to Female Genital Cutting in the Gambia. ICRW \& CEDPA: The Foundation for Research on Women's Health, Productivity and the Environment. http://www.bafrow.org accessed 02/07/2007.

Barstow, D. (1998) Female Genital Mutilation: The Penultimate Gender Abuse. USA: University of Central Oklahoma. www.sciencedirect.com accessed 27/04/2007.

Baumgarten, I. (2001) Addressing Female Genital Mutilation: Challenges and Perspectives for Health Programmes - Part 1: Select Approaches. Eschborn: GTZ. http://www.gtz.de/de/ dokumente/en-fgm-addressing-fgm.pdf.

Behrendt, A., and Moritz, S. (2005) 'Post Traumatic Stress Disorder and Memory Problems After Female Genital Mutilation' in American Journal of Psychiatry, 162 (5), pp. 1000-2.

Black, JA and Debelle, GD. (1995) 'Female Genital Mutilation in Britain' in British Medical Journal, 310, pp. 1590-1592. 
Bosch, X. (2001) 'Female genital mutilation in developed countries' in The Lancet; 358, pp. 11771179.

Brady, M. (1999) 'Female Genital Mutilation and the Risk of HIV Transmission' in Journal of Aids, Patient Care and STDs, 13 (12), pp.709-716.

Chege, J. (2004) Testing the Effectiveness of Integrating Community-Based Approaches for Encouraging Abandonment of Female Genital Cutting into CARE's Reproductive Health Programmes in Ethiopia and Kenya. USA: Population Control Frontiers \& USAID.

Chege, J. et al., (2001) An Assessment for Alternative Rites Approach for Encouraging the Abandonment of FGM in Kenya. USA: Population Council. http://www.popcouncil.org/pdfs/frontiers/FR_FinalReports/Kenya_FGC.pdf

Comhlámh (2002) Understanding Female Genital Mutilation (Also Known As Female Genital Circumcision): An Information and Educational Booklet. Dublin: Comhlámh.

Conroy. R. (2006) 'Female Genital Mutilation: Whose Problem, Whose Solution?' in British Medical Journal, 333, pp. 106-107.

Cook, R.J. et al., (2002) 'Female Genital Cutting (Mutilation/Circumcision): Ethical and Legal Dimensions' in International Journal of Gynaecology and Obstetrics, 79, pp. 281-287.

Council of Europe. (2005) Children's Rights Under the European Social Charter: Information Document Prepared by the Secretariat of the ESC, 18 November, 2005. www.coe.int/t/e/human_ rights/esc/7_resources/factsheet_children.pdf

Council of Europe. (2001) Council of Europe. Parliamentary Assembly Resolution 1247 on Female Genital Mutilation.

http://assembly.coe.int/Main.asp?link=/Documents/AdoptedText/ta01/ERES1247.htm accessed on 25/06/2007.

CSO (2006) Central Statistics: Population Classified by Religion and Nationality, Dublin: Central Statistics Office. www.cso.ie accessed on 01/05/07.

Dáil Eireann, (2006) Written Answers - Human Rights Issues. Minister for Justice, Equity and Law Reform, Michael McDowell in reply to Caoimhghin O Caolain. Volume 616, 9 March. http://debates.oireachtas.ie/Main.aspx accessed on 01/05/2007.

Denholm, N. (1998) Female genital mutilation in New Zealand: understanding and responding: a manual for health professionals. New Zealand: FGM Education.

DoHC (2006) Cultural Male Circumcision. Report of the Committee 2004/2005. Dublin: Department of Health \& Children. http://www.dohc.ie/publications/pdf/circumcision. pdf?direct $=1$ 
DeSilva, S. (1989) 'Obstetric Sequelae of Female Circumcision' in European Journal of Obstetric and Gynaecological Reproductive Biology, 32, pp. 233-240.

Development Gateway Foundation (2007) 'Speaking Out: Stopping Female Genital Mutilation/ Cutting.http://topics.developmentgateway.org/gender?intcmp=911 accessed on 04/07/2007.

Donnelly, V. (2001) 'Trying to stop a barbaric practice' The Irish Times, 5th March.

Elchalal, U. et al., (1997) Ritualistic Female Genital Mutilation: current status and future outlook.' in Obstetrical and Gynecological Survey, 52, pp. 643-651.

El Dareer, A. (1983) 'Complications of Female Circumcision in the Sudan' in Tropical Doctor, 13, pp. 131-133.

El-Defrawi, M. et al., (2001) 'Female Genital Mutilation and its Psychosexual Impact' in Journal of Sex and Marital Therapy, 27, pp. 465-473.

Eliah, E. (1996) 'Reaching for a healthier future' in Populi, (May), pp. 12-16.

EU (2000) Charter of the Fundamental Rights of the European Union, http://www.europarl. europa.eu/charter/default_en.htm

EU (2003) Declaration on the Elimination of Violence against Women

Figueroa, M. et al., (2002) Communication for Social Change: An Integrated Model for Measuring Process and its Outcomes - Communication for Social Change Working Paper Series No. 1. New York: The Rockefeller Foundation.

FORWARD (2007) Fistula. http://www.forwarduk.org.uk/key-issues/fistula accessed on $16 / 08 / 2007$.

Gill, D. et al., (2006) Cultural Male Circumcision: Report of the Committee, 2004-2005. Dublin: Department of Health and Children. www.dohc.ie, accessed on 02/07/2007.

Gruenbaum, E. (2005) 'Socio-cultural dynamics of female genital cutting: Research findings, gaps, and directions' in Culture, Health and Sexuality, 7 (5), pp. 429-441.

Habtemarian, G. et al., (2003) 'Impact of Community Based Education on a FGM in Rural Ethiopian Community. A paper presented at The 31st Annual Meeting and Exposition of the American Public Health Association. San Francisco: American Public Health Association.

Houses of the Oireachtas (2001) Prohibition of Female Genital Mutilation Bill. http://www. oireachtas.ie/documents/bills28/bills/2001/1501/b1501.pdf 
Houses of the Oireachtas (1997) Non-Fatal Offences against the Person Act, 1997. Accessible at http://www.bailii.org/ie/legis

Hosken, F.P. (1993) The Hosken Report: The Genital and Sexual Mutilation of Females.

Massachusetts: Women's International Network News.

ICCL (2000) Women and the Refugee Experience: Towards a Statement of Best Practice. Dublin:

ICCL Women's Committee. www.iccl.ie/DB_Data/publications/WomenandtheRefugeeExperie nce1.pdf

Irish Medical News (2007) 'Doctors urged to report female genital mutilation' in Irish Medical News, 24 (32).

http://www.irishmedicalnews.ie/articles.asp?Category=news\&ArticleID=19356

IPPF(2007) 'The Link between Female Genital Mutilation and HIV Transmission'. http://www. ippf.org/en/News/Intl+news/The+Link+Between+Female+Genital+Mutilation+And+HIV+Tra nsmission.htm, accessed on 20/11/07.

Jabre, B., Underwood, C., and Goodsmith, L. (1997) Arab Women Speak Out: Profiles of Self Empowerment. Baltimore: John Hopkins Centre for Communication Programmes and Centre of Arab Women's Training and Research.

Jager, F., et al., (2002) 'Female Genital Mutilation in Switzerland: A Survey Among Gynecologists' in Swiss Medical Weekly, 132, pp. 259-264.

Jones, J. (2000) 'Concern Mounts Over Female Genital Mutilation' in British Medical Journal, 321, pp. 262.

Karim, M. (1993) Circumcisions and Mutilations: Male and Female. Cairo: The Egyptian National Council of the Population.

Khaled, K., and Vause, S. (1996) 'Genital Mutilation - A Continued Abuse' in British Journal of Obstetrics and Gynaecology, 103, pp. 86-7.

Kun, K. (1997) 'Female genital mutilation: the potential for increased risk of HIV infection' in International Journal of Gynecology \& Obstetrics, 59 (2), pp. 153-155.

Lax, R.F. (2000) 'Socially sanctioned violence against women: female genital mutilation in its most brutal form' in Clinical Social Work Journal, 28, pp. 402-412.

Lentin, R., and McVeigh, R. (2006) After optimism? : Ireland, racism and globalization. Dublin: Metro Éireann Publications.

Lewnes, A. (2005) Changing a Harmful Social Convention: Female Genital Mutilation/Cutting. Florence: UNICEF. 
Leye, E. and Deblonde, J. (2004) Legislation in Europe Regarding Female Genital Mutilation and the Implementation of the Law in Belgium, France, Spain and the UK. Belgium: International Centre for Reproductive Health.

Leye, E. et al., (2006) 'Healthcare in Europe for Women with Female Genital Mutilation' in Health Care for Women International, 27, pp. 362-378.

Lightfoot-Klein, H. (1989) 'The Sexual Experience and Marital Adjustment of Genitally Circumcised and Infibulated Females in the Sudan' in The Journal of Sex Research, 26 (3), pp. 375-392.

Lightfoot-Klein, H. (1991)'Prisoners of ritual: some contemporary developments in the history of Female Genital Mutilation', Paper presented at the Second International Symposium on Circumcision in San Francisco, April-30 - May 3, 1991 http://www.fgmnetwork.org/authors/ Lightfoot-klein/prisonersofritual.htm accessed on 02/07/2007.

Lisy, K. (2007) Promotion of Initiatives to End Female Genital Mutilation (FGM). Germany: Supra-Regional Project. www.gtz.de/fgm

Lundberg, P. and Gerezgiher, A. (2006) 'Experiences from Pregnancy and Childbirth related to Female Genital Mutilation among Eritrean Immigrant Women in Sweden' in Midwifery, 10 (1016), pp. 1-11.

MacLachlan, M. (2006) Culture and Health: a critical perspective towards global health. 2nd Edition. Chichister: John Wiley and Sons Ltd.

Masterson, J. and Swanson, J. (2000) Female Genital Cutting: Breaking the Silence, Enabling Change. Washington: International Centre for Research on Women (ICRW). www.icrw.org/docs/ FGMfinalpdf.pdf

McCaffrey, M. et al., (1995) 'Management of female genital mutilation: the Northwick Park Hospital experience' in British Journal of Obstetrics and Gynaecology, 102, pp. 787-790.

McCloud, P. et al., (2003) Promoting FGM Abandonment in Egypt. Washington: CEDPA.

McCulloch, S. (2004) 'Female Genital Mutilation Conference - Birmingham'. Birmingham: The Agency for Culture and Change Management (ACCM).

McMeel, C. (2005) General Practice Care in a Multi-Cultural Society: A Guide to Interpretation Services and Cultural Competency. Dublin: ICGP.

Meleis, A.I. (2003)'Theoretical considerations of health care for immigrant and minority women' in St. Hill, P., Lipson, J.G., and Meleis, A.I. (eds), Caring for women cross-culturally. Philadelphia: F.A. Davis Company. 
Miller, M. (2004) Responses to Female Genital Mutilation/Cutting in Europe. Florence: UNICEF Innocenti Research Centre. http://www.unicef-irc.org/research/pdf/Responses\%20to\%20FGM C\%20Europe.pdf

Momoh, C. (ed) (2005) Female Genital Mutilation. Abingdon: Radcliffe.

Momoh, C. et al., (2001) 'Female Genital Mutilation: Analysis of the first twelve months of a southeast London specialist clinic' in British Journal of Obstetrics and Gynaecology, 108, pp. 186-191.

Morris, R.I. (1999) 'Female Genital Mutilation: Perspectives, Risks and complications' in Urological Nursing, 19, pp.13-19.

Muecke, M. (1992) 'New Paradigms for Refugee Health Problems' in Social Science and Medicine, 35 (4), pp. 703-20.

Munanie, E. (2001) Female Genital Mutilation: Knowledge, Attitudes and Responses Amongst Communities and Health Professionals. London: Foundation for Women's Health Research and Development (FORWARD).

Munro, K. (2005) Cultural Care in Gynecology: A Report of the Review of Gynecological Service Response to Women from Minority Ethnic Communities in North Glasgow. Scotland: Glasgow Royal Infirmary.

Murphy, K. (2006) 'Female Genital Mutilation' in Women's News: Irish Feminist Magazine. Belfast: Irish Feminist Organisation. Issue No. 159.

Mutenbei, I.B, and Mwesiga, M.K. (1998)'The Impact of Obsolete Traditions on HIV/AIDS rapid transmission in Africa: The case of compulsory circumcision on young girls in Tanzania. (Abs 23473)' at The International Conference on AIDS, 1998; 12:436, cited in M. Brady (1999) 'Female Genital Mutilation and the Risk of HIV Transmission' in Journal of Aids, Patient Care and STD's, 13 (12), pp.709-716.

Muteshi, J. and Sass, J. (2005) Female Genital Mutilation in Africa: An Analysis of Current Abandonment Approaches. Nairobi: PATH.

Mutwarasibo, F. and Smith, S. (2000) Africans in Ireland:Developing Communities. Dublin: The African Cultural Project. http://web.mac.com/greville1/iweb/Africa, accessed on 06/05/2007.

Mwangi-Powell, F. (2001a) Female Genital Mutilation: Holistic Care for Women - A Practical Guide for Midwives. London: Foundation for Women's Health Research and Development (FORWARD).

Mwangi-Powell, F. (2001b) Female Genital Mutilation: A Case Study in Birmingham. London: Foundation for Women's Health Research and Development (FORWARD). 
National Council for Childhood and Motherhood, Egypt (2003) 'Afro-Arab Expert Consultation: Legal Tools for the Prevention of Female Genital Mutilation' Cairo: 23rd June 2003. http://www. childinfo.org/areas/fgmc/docs/Cairo\%20declaration.pdf

NCCRI (2007) Improving Government Services to Minority Ethnic Groups: Key Considerations for Service Providers. Dublin: NCCRI. http://www.nccri.ie/pdf/KeyConsiderations.pdf

Njoroge, A. (2005) Maputo Protocol

http://www.emmabonino.it/campagne/stopfgm/djibouti/njoroge.pdf

No Peace Without Justice (2007) 'FGM Legislation for 25 African Countries'. http://www.npwj. org/tf/maputo/

Nwajei, S. and Otiono, I. (2003) 'Female Genital Mutilation: Implications for Female Sexuality' in Women's Studies International Forum, 26 (6), pp. 575-580.

Ouoba, D. (2003) Involving Men to Abandon Female Genital Cutting: A Community Based Education Program in Burkina Faso (September 15-18, 2003). Washington: Mwangaza Action.

Pellegrino, R. (2007) 'In Gambia per essere infibulate Giudice spagnolo vieta l'espatrio' ('Spanish judge stops travel to Gambia for "infibulation") in // Gornale, 25th June 2007.

Pillinger, J. (2007) 'The situation and experience of women migrant workers in Ireland' pp. 4247. in K. Kolthoff (ed.), Equal Rights, Equal Voices: Migrant Women in the European Union, 19-21 January.

Pinheiro, P.S. (2006) World Report on Violence Against Children. Geneva: United Nations. http://www.unviolencestudy.org/

Poldermans, S. (2006) Combating Female Genital Mutilation in Europe: A Comparative Analysis of Legislative and Preventative Tools in the Netherlands, France, The United Kingdom and Austria. Submitted in part for a European Masters Degree in Human Rights and Democratization: University of Vienna, Austria. www.stopfgm.net/dox/SPoldermansFGMinEurope.pdf

Population Reference Bureau (2005) 'Female Genital Mutilation in Cameroon' in Abandoning Female Genital Mutilation/Cutting: Information from Around the World. Washington: USAID.

Powell, R. et al., (2004) 'Female Genital Mutilation, Asylum Seekers and Refugees: The Need for an Integrated European Agenda' in Health Policy, 70, pp. 151-162.

RAINBO (2004) Review of Past Approaches: The Female Genital Mutilation - Review, Evaluation and Monitoring Project. www.rainbo.org 
Rahman, A. and Toubia, N. (eds.) (2000) Female Genital Mutilation: A Guide to Laws and Policies Worldwide. London: Zed Books.

Rajadurai, H. and Igras, S. (2005) At the Intersection of Health, Social Well-Being and Human Rights: CARE's Experiences Working With Communities Towards Abandonment of Female Genital Cutting. CARE. http://www.care.org/careswork/whatwedo/health/downloads/FGC_abandonment.pdf

Royal College of Midwives (1998) Female Genital Mutilation (Female Circumcision): Position Paper No. 21. London: Royal College of Midwives.

Sami, J. and El-Dareer, A. (1983) 'Complications of Female Circumcision in the Sudan' in Tropical Doctor, 13, pp. 131-133.

Sansani, I. (2001) The Provision of Health Services in Ireland for Women who have Survived Gender Based Torture. Dublin: M.Phil. Ethnic and Racial Studies Trinity College, Dublin.

Shell-Duncan, B. (2001) 'The Medicalisation of Female 'Circumcision': Harm Reduction or promotion of a dangerous practice?' in Social Science and Medicine, 52, pp. 1013-1028.

SPIRASI (2007) SPIRASI: Strategic Plan, 2007-09. Dublin: SPIRASI.

Thabet, S. and Thabet, A. (2001) 'Defective Sexuality and Female Circumcision: The Cause and Possible Management' in Journal of Obstetrics and Gynaecological Research, 29 (1), pp. 12-19.

Thierfelder, C. et al., (2005) 'Female Genital Mutilation in the Context of Migration: Experiences of African Women in the Swedish Healthcare System' in European Journal of Public Health, 15 (1), pp. 86-90.

Tomkin, R. (1999) From Normalisation to Stigma: Approaches to Providing Health Care to Refugees in Ireland. Trinity College Dublin: M. Phil. Ethnic and Racial Studies Masters Dissertation: Unpublished.

Tostan (1999) Breakthrough in Senegal: A Report on the Process to End Female Genital Cutting in 31 Villages. New York: Population Council.

Toubia, N. and Sharief, E. (2003) 'Female Genital Mutilation: Have We Made Progress?' in International Journal of Gynecology and Obstetrics, 82, pp. 251-261.

Toubia, N. (1999) Caring for Women with Circumcision, a Technical Manual for Healthcare Providers. New York: Rainbo.

UN (1979) Convention on the Elimination of all Forms of Discrimination against Women (CEDAW), http://www.un.org/womenwatch/daw/cedaw 
UNHCR (1993) Declaration on the Elimination of Violence against Women: General Assembly resolution 48/104, http://www.unhchr.ch/huridocda/huridoca.nsf/(Symbol)/A.RES.48.104.En

UNICEF (2007) The State of the World's Children 2007: The Double Dividend of Gender Equality. New York: UNICEF.

UNICEF (2005) Female Genital Mutilation/Cutting: A Statistical Exploration. New York: UNICEF. http://www.unicef.org/publications/index_29994.html

UNICEF (1998) Niger FGM/C Country Profile. Niger: DHS.

UNIFEM (2003) Not a Minute More: Ending Violence Against Women. New York: United Nations Development Fund for Women. Accessible at www.unp.un.org

UNFPA (2006) 'Obstetric Fistula in Brief'. www.endfistula.org/fistula_brief.htm, accessed on 23/05/07.

UNFPA (2004) 24 Tips for Culturally Sensitive Programming. New York: UNFPA.

United Kingdom (2003) The Female Genital Mutilation Act. http://www.opsi.gov.uk/ACTS/ acts2003/20030031.htm

United Kingdom (1985) Prohibition of Female Circumcision Act. http://www.statutelaw.gov.uk

Valderrama, J. (2002) 'Female Genital Mutilation: why are we so radical?' in The Lancet, 359, pp. 529-30.

Vangen, S. et al., (2004) 'Qualitative Study of Perinatal Care Experiences Among Somali Women and Local Health Care Professionals in Norway' in European Journal of Obstetrics and Gynecology, 112, pp. 29-35.

Wabaki, W. (2007) 'Africa Battles to Make Female Genital Mutilation History' in The Lancet, 39, pp. 1069-1070.

Watt, P. and McGaughey, F. (2006) Improving Government Services to Ethnic Minorities. Dublin: NCCRI. http://www.nccri.ie/pdf/Service_Provision.pdf

West, B. (2003) 'Synergies in Deviance: Revisiting the Positive Deviance Debate' in Electronic Journal of Sociology, 17 (4). www.sociology.org/content/vol17.4/west.html

WHO (2006) 'Female Genital Mutilation and Obstetric Outcome: A Collaborative Prospective Study in six African Countries' in The Lancet: 367, pp. 1835-41.

WHO (2000) Female Genital Mutilation, Fact Sheet No. 241. Geneva: World Health Organization. 
WHO (1999) Female Genital Mutilation: Programmes to Date - What Works and What Doesn't. Geneva: World Health Organization.

WHO/UNICEF/UNFPA (1997) Female Genital Mutilation: A Joint WHO/UNICEF/UNFPA Statement. Geneva: World Health Organization.

Whitehorn, J. et al., (2002) 'Female Genital Mutilation: Cultural and Psychological Implications' in Sexual and Relationship Therapy, 17 (2), pp. 161-170.

Women's Health Council (2006) Submission to the HSE: National Intercultural Health Strategy. Dublin: The Women's Health Council.

http://www.whc.ie/publications/Submission_InterculturalHealth.pdf

Yoder, P., Mahy, S., and Mahy, M. (2001) Female Genital Cutting in Guinea: Qualitative and Quantitative Research Strategies. ORC Macro Calverton, USA: Maryland.

Yuval-Davis, N. (1997) Gender and Nation. London: Sage. 



\section{The Women's Health Council \\ Combairle Shláinte na mBan}

\section{Women's Health Council}

Block D, Irish Life Centre, Abbey Street Lwr, Dublin 1

Telephone: 35318783777

Fax: 35318783710

Email: info@whc.ie

www.whc.ie 